\title{
Phytochemistry of Camptotheca Decaisne
}

\author{
Shiyou $\mathrm{Li}^{*}$ and Ping Wang
}

National Center for Pharmaceutical Crops, Arthur Temple College of Forestry and Agriculture, Stephen F. Austin State University, Nacogdoches, TX 75962, USA

\begin{abstract}
To date, chemical investigations of the genus Camptotheca have been primarily focused on C. acuminata. Total 78 compounds have been isolated from the species, including alkaloids (1-28), ellagic acids (29-40), flavonoids (41-46), sterols (47-48), terpenes (49-55), tannins (56-71), polyphenols and fatty acids (65-72), iridoid (73), lignan (74), polyols (75 and 76), amide (77), and sacchardide (78). The contents of camptothecin (CPT, 1), the major active alkaloid varies significantly with Camptotheca species and varieties, tissue and tree age and seasonal changes. Among all taxa of Camptotheca, C. acuminata var. acuminata has the lowest CPT contents $(0.2249-0.3162 \%$ in young leaves, and $0.0392-$ $0.0572 \%$ in older leaves). C. lowreyana "Hicksii" has the highest CPT contents in both young and old leaves, approximately 1.5-2 folds higher than those in C. acuminata var. acuminata. Young leaves and mature fruits have high CPT contents than other tissues in Camptotheca. In young tissues of C. acuminata var. acuminata, the lowest CPT levels were found in March and April (0.074\% and 0.081\%, respectively) and highest in June (0.265\%).
\end{abstract}

Keywords: Alkaloids, Camptotheca, Camptothecin variations, Camptothecins (CPTs), Ellagic acids, Flavonoids, sterols, Terpenes.

\section{CHEMICAL CONSTITUENTS}

The report of chemical constituents of Camptotheca has been restricted to C. acuminata. To date, 78 compounds have been isolated from C. acuminata, including alkaloids (1-28), ellagic acids (29-40), flavonoids (41-46), sterols (47-48), terpenes (49-55), tannins (56-71), polyphenols and fatty acids (65-72), iridoid (73), lignan (74), polyols (75 and 76), amide (77), and sacchardide (78) (Fig. 1 and Table 1).

\begin{abstract}
Alkaloids
Camptothecin (CPT, 1), a pyrrolo[3,4-b]-quinoline alkaloid, was first identified from the stem wood of C. acuminata in 1966 by Dr. Monroe E. Wall and Dr. Mansukh C. Wani of Research Triangle Institute in systematic screening of natural products for anticancer drugs [1]. In 1969, Dr. Wani and Dr. Wall had also first isolated two minor and related components 10-hydroxycamptothecin (10-HCPT, 2) and 10-methoxycamptothecin (4) by further fractionation of the stem wood of C. acuminata. Compounds $\mathbf{1}$ and $\mathbf{2}$ were also found to occur in other plant parts, including leave [2], stem bark [2], fruit [2, 3], and root [2, 4]. Since then C. acuminata is considered to be a rich plant source of the potent camptothecinoids. This class is characterized by a pentacyclic ring structure embodying pyrrolo[3,4-b]-quinoline moiety (rings A, B and C), conjugated pyridone moiety (ring D) and a chiral centre within a six membered $\alpha$-hydroxy lactone (ring E) [5]. This planar pentacyclic ring structure is thought to be one of the most important factors in inhibition of DNA topoisomerase I. Oxygenation is also usually observed at $\mathrm{C}-10$ and $\mathrm{C}-11$ and often at $\mathrm{C}-18$ and $\mathrm{C}-20$.

*Address correspondence to this author at the National Center for Pharmaceutical Crops, Arthur Temple College of Forestry and Agriculture, Stephen F. Austin State University, Nacogdoches, TX 75962, USA;

Tel: 936-468-2071; Fax: 936-468-7058; E-mail: 1is@sfasu.edu
\end{abstract}

The oxygenated positions may be present either as hydroxyl and methoxy groups or occasionally ester or glucose (Table 1). So far 10 quinoline camptothecinoids $(\mathbf{3}, \mathbf{5 - 1 3})$ have been reported by scientists in the United States, China, and Japan. 10-hydroxy-20-deoxycamptothecin (3) was isolated by Lin and coworkers in 1989 from the fruit of $C$. acuminata and possessed a strong cytotoxicity against P388 leukemia cell [6]. Two new camptothecinoids 10 -methoxy-20- $O$-acetylcamptothecin (5) and 20- $\beta$-Dglucopyranosyl 18-hydroxycamptothecin (13), together 10methoxycamptothecin (4), 18-hydroxycamptothecin (8), 20-O-acetylcamptothecin (10) and 20-deoxycamptothecin (12) were isolated from root bark and leaf of C. acuminata by Zhang et al. in 2004 [2]. Hsu et al. in 1977 [3], and Lin et al., in 1978, 1979 and 1982 [7-9] isolated 11hydroxycamptothecin (6), 11-methoxycamptothecin (7), respectively, together with 10-methoxycamptothecin (4) and 20-deoxycamptothecin (12) from the fruit of C. acuminata. 18-hydroxycamptothecin (8) was also found from the fruit of $C$. acuminata [10]. Two minor camptothecinoids 20-hexanoylcamptothecin (9), 20-hexanoyl-10-methoxycamptothecin (11) with one known compound 12 were identified from stem bark of C. acuminata in 1979 [11]. Compound 20-deoxycamptothecin (12) was reported as a minor camptothecinoid from the fruit of C. acuminata [12]. 20formylbenz [6,7] indolizino[1,2-b]quinoline-11 (13H)-one (14), 22-hydroxyacuminatine (15), and 19-hydroxymappicine (18) are three minor quinoline alkaloids isolated from the root of C. acuminata [2] and the fruit of C. acuminata [13].

Five minor indole alkaloids were reported, including angustoline (16) from the stem and the fruit of $C$. acuminata $[15,16], 19-O$-methylangustoline (17) from the fruit of $C$. acuminata [17], camptacumotine (19), camptacumanine (20), and naucleficine (21) isolated from the fruit of 


$$
\text { (1) }
$$

$1 \mathrm{R}_{1}=\mathrm{H}, \mathrm{R}_{2}=\mathrm{H}, \mathrm{R}_{3}=\mathrm{CH}_{3}, \mathrm{R}_{4}=\mathrm{OH}$

$2 \mathrm{R}_{1}=\mathrm{OH}, \mathrm{R}_{2}=\mathrm{H}, \mathrm{R}_{3}=\mathrm{CH}_{3}, \mathrm{R}_{4}=\mathrm{OH}$

$3 \mathrm{R}_{1}=\mathrm{OH}, \mathrm{R}_{2}=\mathrm{H}, \mathrm{R}_{3}=\mathrm{CH}_{3}, \mathrm{R}_{4}=\mathrm{H}$

$4 \mathrm{R}_{1}=\mathrm{OCH}_{3}, \mathrm{R}_{2}=\mathrm{H}, \mathrm{R}_{3}=\mathrm{CH}_{3}, \mathrm{R}_{4}=\mathrm{OH}$

$5 \mathrm{R}_{1}=\mathrm{OCH}_{3}, \mathrm{R}_{2}=\mathrm{H}, \mathrm{R}_{3}=\mathrm{CH}_{3}, \mathrm{R}_{4}=\mathrm{OAC}$

$6 \mathrm{R}_{1}=\mathrm{H}, \mathrm{R}_{2}=\mathrm{OH}, \mathrm{R}_{3}=\mathrm{CH}_{3}, \mathrm{R}_{4}=\mathrm{OH}$

$7 \mathrm{R}_{1}=\mathrm{H}, \mathrm{R}_{2}=\mathrm{OCH}_{3}, \mathrm{R}_{3}=\mathrm{CH}_{3}, \mathrm{R}_{4}=\mathrm{OH}$

$8 \mathrm{R}_{1}=\mathrm{H}, \mathrm{R}_{2}=\mathrm{H}, \mathrm{R}_{3}=\mathrm{CH}_{2} \mathrm{OH}, \mathrm{R}_{4}=\mathrm{OH}$

$9 \mathrm{R}_{1}=\mathrm{H}, \mathrm{R}_{2}=\mathrm{H}, \mathrm{R}_{3}=\mathrm{CH}_{3}, \mathrm{R}_{4}=\mathrm{OCO}\left(\mathrm{CH}_{2}\right)_{4} \mathrm{CH}_{3}$

$10 \mathrm{R}_{1}=\mathrm{H}, \mathrm{R}_{2}=\mathrm{H}, \mathrm{R}_{3}=\mathrm{CH}_{3}, \mathrm{R}_{4}=\mathrm{OAC}$

$11 \mathrm{R}_{1}=\mathrm{OCH}_{3}, \mathrm{R}_{2}=\mathrm{H}, \mathrm{R}_{3}=\mathrm{CH}_{3}, \mathrm{R}_{4}=\mathrm{OCO}\left(\mathrm{CH}_{2}\right)_{4} \mathrm{CH}_{3}$

$12 \mathrm{R}_{1}=\mathrm{H}, \mathrm{R}_{2}=\mathrm{H}, \mathrm{R}_{3}=\mathrm{CH}_{3}, \mathrm{R}_{4}=\mathrm{H}$

$13 \mathrm{R}_{1}=\mathrm{H}, \mathrm{R}_{2}=\mathrm{H}, \mathrm{R}_{3}=\mathrm{CH}_{2} \mathrm{OH}, \mathrm{R}_{4}=\beta$-D-glucopyranosyl

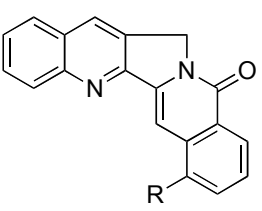

$14 \mathrm{R}=\mathrm{CHO}$ $15 \mathrm{R}=\mathrm{CH}_{2} \mathrm{OH}$<smiles>[R]OC(C)c1cncc2c(=O)n3c(cc12)-c1c([nH]c2ccccc12)C3</smiles>

$16 \mathrm{R}=\mathrm{H}$ $17 \mathrm{R}=\mathrm{CH}_{3}$<smiles>C/C=C/C=C/C</smiles>

18<smiles>CC1Cc2cc3n(c(=O)c2C(=O)O1)CCc1c-3[nH]c2ccccc12</smiles>

19<smiles>COC1=COC(C)c2cc3n(c(=O)c21)CCc1c-3[nH]c2ccccc12</smiles>

20<smiles>O=Cc1cccc2c(=O)n3c(cc12)-c1c([nH]c2ccccc12)C3</smiles>

21<smiles>C=CC1C(O[C@H]2OC(O)C(O)C[C@H]2O)OC=C2C(=O)N3Cc4c(c5[nH]c(c4=O)=CC=CC=5)[C@@H]3CC21</smiles>

25<smiles>[R6]Oc1c([R2])c2c3c(c([R])c(O[R20])c4c3c1C(=O)OC4=O)OCO2</smiles><smiles>[R3]Oc1c([R4])c([R3])c2c(=O)oc3c([R])c([R20])cc4c(=O)oc1c2c34</smiles><smiles>C=CC1C(O)OC=C2C(=O)N3CCc4c([nH]c5ccccc45)[C@@H]3CC21</smiles><smiles>OCC1OCC(O)C(O)C1O</smiles>

22<smiles>CCC1CN(C)C2OC3c4ccccc4NC1(CO)C32</smiles><smiles>CC1c2cnccc2C[C@H]1O</smiles>

27<smiles>C=CC1C(O)OC=C2C(=O)N3CCc4c([nH]c5ccccc45)C3CC21</smiles><smiles>OC1COC(O)C(O)C1O</smiles>

23<smiles>O=C(O)c1cc(=O)[nH]c2ccccc12</smiles>

28
$29 \mathrm{R}_{1}=\mathrm{H}, \mathrm{R}_{2}=\mathrm{CH}_{3}, \mathrm{R}_{3}=\mathrm{H}, \mathrm{R}_{4}=\mathrm{OH}$

$30 \mathrm{R}_{1}=\mathrm{H}, \mathrm{R}_{2}=\mathrm{CH}_{3}, \mathrm{R}_{3}=\beta$-D-glucopyranosyl, $\mathrm{R}_{4}=\mathrm{H}$

$31 \mathrm{R}_{1}=\mathrm{H}, \mathrm{R}_{2}=\mathrm{CH}_{3}, \mathrm{R}_{3}=\mathrm{CH}_{3}, \mathrm{R}_{4}=\mathrm{OCH}_{3}$

$32 \mathrm{R}_{1}=\mathrm{H}, \mathrm{R}_{2}=\mathrm{CH} 3, \mathrm{R}_{3}=\mathrm{CH} 3, \mathrm{R}_{4}=\mathrm{OH}$

$33 \mathrm{R}_{1}=\mathrm{OCH}_{3}, \mathrm{R}_{2}=\mathrm{CH}_{3}, \mathrm{R}_{3}=\mathrm{CH}_{3}, \mathrm{R}_{4}=\mathrm{OCH}_{3}$

$34 \mathrm{R}_{1}=\mathrm{H}, \mathrm{R}_{2}=\mathrm{H}, \mathrm{R}_{3}=\mathrm{H}, \mathrm{R}_{4}=\mathrm{H}$

$35 \mathrm{R}_{1}=\mathrm{H}, \mathrm{R}_{2}=\mathrm{CH}_{3}, \mathrm{R}_{3}=\mathrm{H}, \mathrm{R}_{4}=\mathrm{H}$

$36 \mathrm{R}_{1}=\mathrm{H}, \mathrm{R}_{2}=\mathrm{CH}_{3}, \mathrm{R}_{3}=\mathrm{CH}_{3}, \mathrm{R}_{4}=\mathrm{H}$

$37 \mathrm{R}_{1}=\mathrm{CH}_{3}, \mathrm{R}_{2}=\mathrm{CH}_{3}, \mathrm{R}_{3}=\mathrm{CH}_{3}, \mathrm{R}_{4}=\mathrm{H}, \mathrm{R}_{5}=\mathrm{H}$

$38 \mathrm{R}_{1}=\mathrm{CH}_{3}, \mathrm{R}_{2}=\mathrm{CH}_{3}, \mathrm{R}_{3}=\mathrm{CH}_{3}, \mathrm{R}_{4}=\beta$-D-glucopyranosyl, $\mathrm{R}_{5}=\mathrm{H}$

$39 \mathrm{R}_{1}=\mathrm{CH}_{3}, \mathrm{R}_{2}=\mathrm{H}, \mathrm{R}_{3}=\mathrm{H}, \mathrm{R}_{4}=\mathrm{CH}_{3}, \mathrm{R}_{5}=\mathrm{H}$

$40 \mathrm{R}_{1}=\mathrm{CH}_{3}, \mathrm{R}_{2}=\mathrm{CH}_{3}, \mathrm{R}_{3}=\mathrm{CH}_{3}, \mathrm{R}_{4}=\mathrm{CH}_{3}, \mathrm{R}_{5}=\mathrm{OCH}_{3}$<smiles>[R2]c1cc(-c2oc3cc(O)cc(O)c3c(=O)c2[R1])ccc1O</smiles>

$41 \mathrm{R}_{1}=\mathrm{H}, \mathrm{R}_{2}=\mathrm{OH}$

$42 \mathrm{R}_{1}=\beta$-D-galactopyranosyl, $\mathrm{R}_{2}=\mathrm{OH}$ $43 \mathrm{R}_{1}=\beta$-D-glucopyranosyl, $\mathrm{R}_{2}=\mathrm{OH}$ $44 \mathrm{R}_{1}=\beta$-D-galactopyranosyl, $\mathrm{R}_{2}=\mathrm{H}$ $45 \mathrm{R}_{1}=\beta$-D-glucopyranosyl, $\mathrm{R}_{2}=\mathrm{H}$ $46 \mathrm{R}_{1}=\mathrm{H}, \mathrm{R}_{2}=\mathrm{H}$

Fig. (1) contd.... 


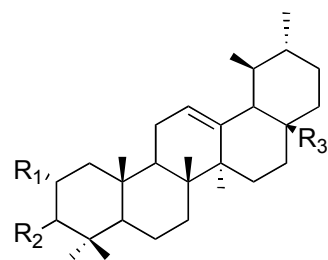

$49 \mathrm{R}_{1}=\mathrm{H}, \mathrm{R}_{2}=\beta-\mathrm{OH}, \mathrm{R}_{3}=\mathrm{COOCH}_{3}$ $50 \mathrm{R}_{1}=\mathrm{H}, \mathrm{R}_{2}=\beta-\mathrm{OH}, \mathrm{R}_{3}=\mathrm{CH}_{3}$ $51 \mathrm{R}_{1}=\mathrm{OH}, \mathrm{R}_{2}=\alpha-\mathrm{OH}, \mathrm{R}_{3}=\mathrm{COOH}$<smiles>C[C@H]1C2COC(=O)CC2C[C@]1(C)O</smiles>

54

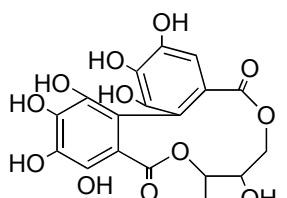<smiles>CC(C=O)C(OC(=O)c1cc(O)c(O)c(O)c1)C(O)CO</smiles><smiles>CCC(OC(=O)c1cc(O)c(O)c(O)c1)C(O)COC(=O)c1cc(O)c(O)c(O)c1</smiles>

56<smiles>CC1=CC(=O)C[C@H](C)[C@H]1/C=C/C(C)=C\C(=O)O</smiles>

55

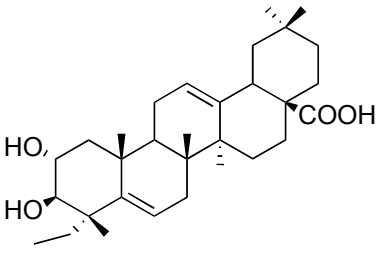

52<smiles>C=C(C)C1CCC2(O)CCC3C(CCC4[C@@]3(C)CCC3[C@]4(C)CC[C@@H](O)[C@]3(C)O)C12</smiles>

53

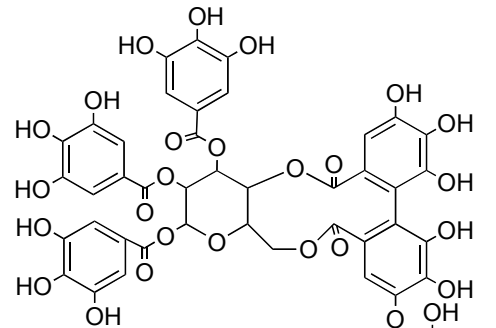

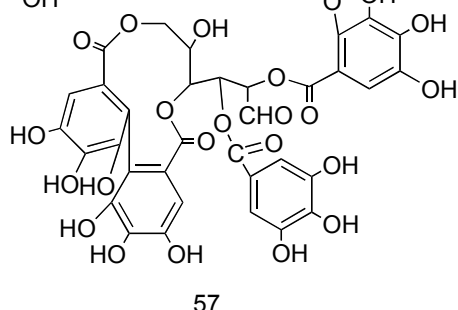

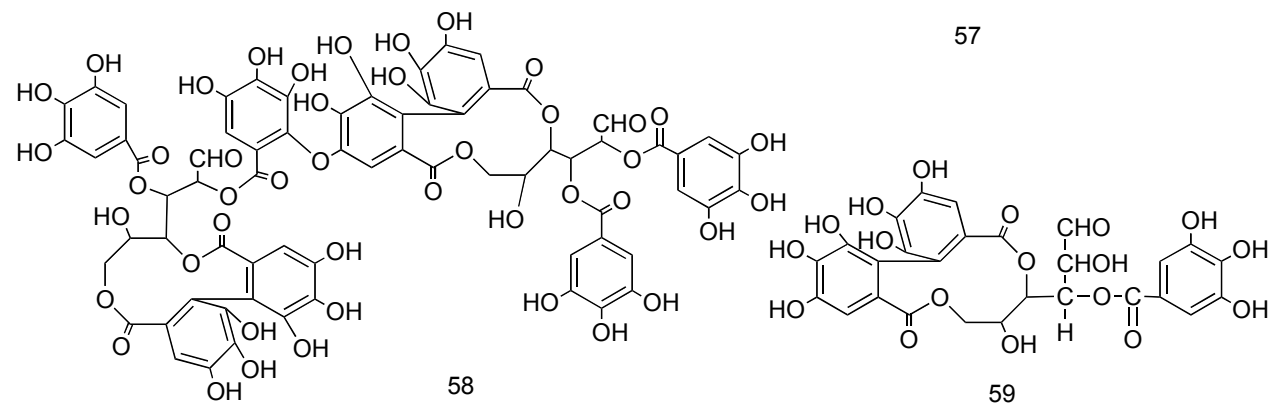

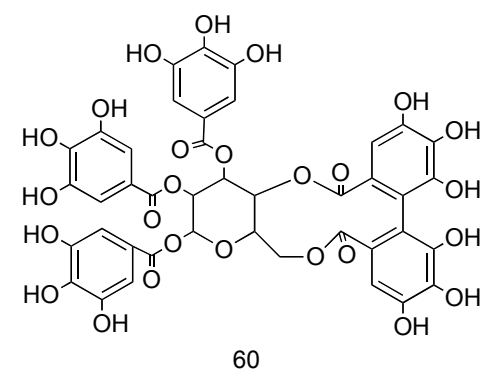

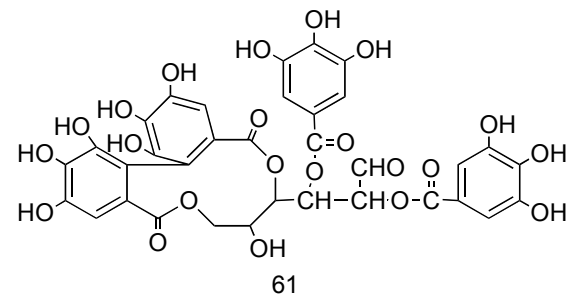

60<smiles>O=C(OC1O[C@H](OC(=O)c2cc(O)c(O)c(O)c2)C(OC(O)c2cc(O)c(O)c(O)c2)C(O)C1O)c1cc(O)c(O)c(O)c1</smiles>

62

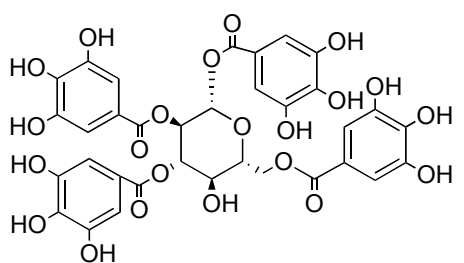

63

Fig. (1) contd.... 


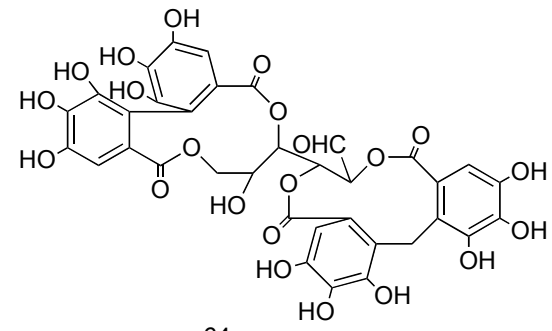

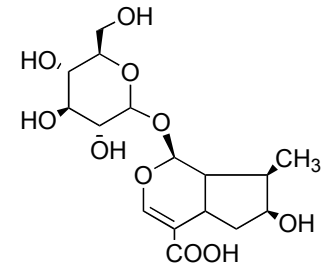

65

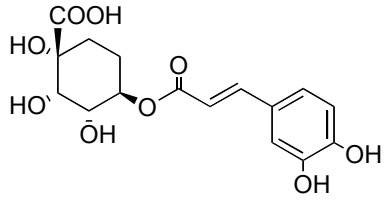

66

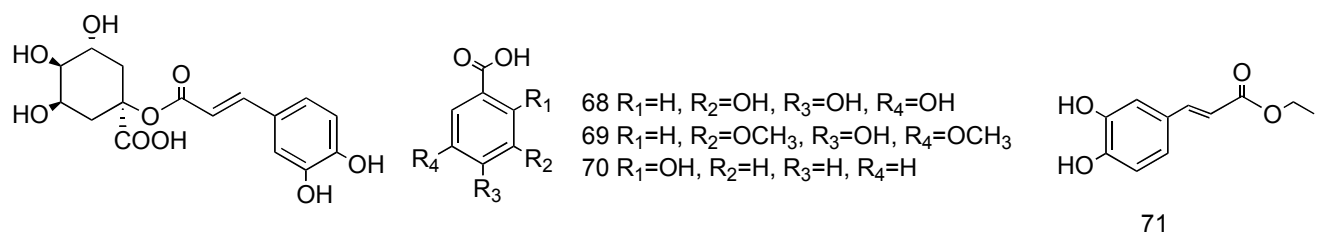

67<smiles>O=C(O)CCCCCCCC(=O)O</smiles>

72<smiles>OC1C(O)C(O)C(O)C(O)C1O</smiles>

75<smiles>CC1CCC(CO)C(CO)C1</smiles>

76<smiles>C=C[C@H]1C2CCOC(=O)C2=CO[C@@H]1OC1O[C@@H](O)C(O)C[C@H]1O</smiles>

73<smiles>COc1cc(C2OCC3C(c4cc(OC)c(O)c(OC)c4)OCC23)cc(OC)c1O</smiles>

$\mathrm{H}_{2} \mathrm{~N}-\stackrel{\mathrm{C}}{-}-\mathrm{CH}_{3}$<smiles>O=C(CO)[C@H](O)[C@H](O)C(O)CO</smiles>

77

78
Fig. (1). Compounds isolated from Camptotheca acuminata.

C. acuminata [16]. In additional, four indole alkaloid glycosides (22-25) were also identified from $C$. acuminata, which are related to the camptothecin biosynthetic pathway (Fig 2). Such as, strictosamide (24) isolated from the leave, stem bark, fruit, and root of C. acuminata [2, 18], and pumiloside (25) from the stem and fruit of C. acuminata [2, 15], might be plausible biogenetic precursors of camptothecin. However, vincosamide (22) $[2,3,18]$ and strictosidinic acid (23) $[2,18]$ are structurally related alkaloids with $\mathbf{2 4}$ and $\mathbf{2 5}$ (Fig. 2). Three simple alkaloids, dihydrosoquinamine (26) [16], venoterpine (27) [3, 4], 1,2-dihydro-2-oxoquinoline-4carboxylic acid (28) [18], were also isolated from the fruit and the root of $C$. acuminata.

\section{Ellagic Acids}

Ellagic acid is a natural phenol antioxidant found in numerous fruits and vegetables. Its antiproliferative and antioxidant properties have showed potential health benefits. There are 12 ellagic acids (29-40) reported from various parts of $C$. acuminata. Most ellagic acid were identified from the fruits, including 3, 4-methylenedioxy-3'-O-methyl4'-O- $\beta$-D-glucopyranosylellagic acid (30) [18], 3, 4-methylenedioxy-3', 4'-O-dimethyl-5'-methoxyellagic acid (31), 3, 4methylenedioxy-3', 4'- $O$-dimethyl-5'-hydroxyellagic acid (32), 3, 4-O,O-methyleneellagic acid (34), 3'-O-methyl-3,4-O,Omethyleneellagic acid (35), 3',4'-O-dimethyl-3,4-O,Omethyleneellagic acid (36), 3, 3', 4- $O$-trimethylellagic acid (37), 3, 4'- $O$-dimethylellagic acid (39), and 3,3',4, 4'- $O$ - tetramethyl-5'-methoxyellagic acid (40) $[8,19]$. Compound 38, 3,3',4- $O$-trimethyl-4'- $O$ - $\beta$-D-glucopyranosylellagic acid, was isolated from the root and stem bark [2]. 3, 4methylenedioxy-3'-O-methyl-5'-hydroxyellagic acid (29) was identified from the root of $C$. acuminata [2]. 3, 4methylenedioxy-3', 4'- $O$-dimethyl-5, 5'-dimethoxylellagic acid (33) was found from the leave of $C$. acuminata [2]. Compounds 30, 31, and 37 were also reported from the root, leave or stem bark of C. acuminata $[2,4]$.

\section{Flavonoids}

Six flavonoids were reported, so far, from the leave of $C$. acuminata $[2,20]$ and the stem bark of $C$. acuminata [2]. It can be observed that four flavonol glycosides, including hyperoside (42), isoquercitrin (43), trifolin (44), and astragalin (45), are quercetin (41) and kaempferol (46) derivatives.

\section{Sterols}

Although the sterols are widely distributed in plant, there are only $\beta$-sitosterol (47) and its glycoside (48) isolated from the fruit of $C$. acuminata [9] and the root of $C$. acuminata $[4,21]$.

\section{Terpenes}

There are five pentacyclic triterpenes (49-53) were isolated from the fruit of $C$. acuminata (49 and 53) $[3,22]$ and 
Table 1. Compounds isolated from Camptotheca acuminata.

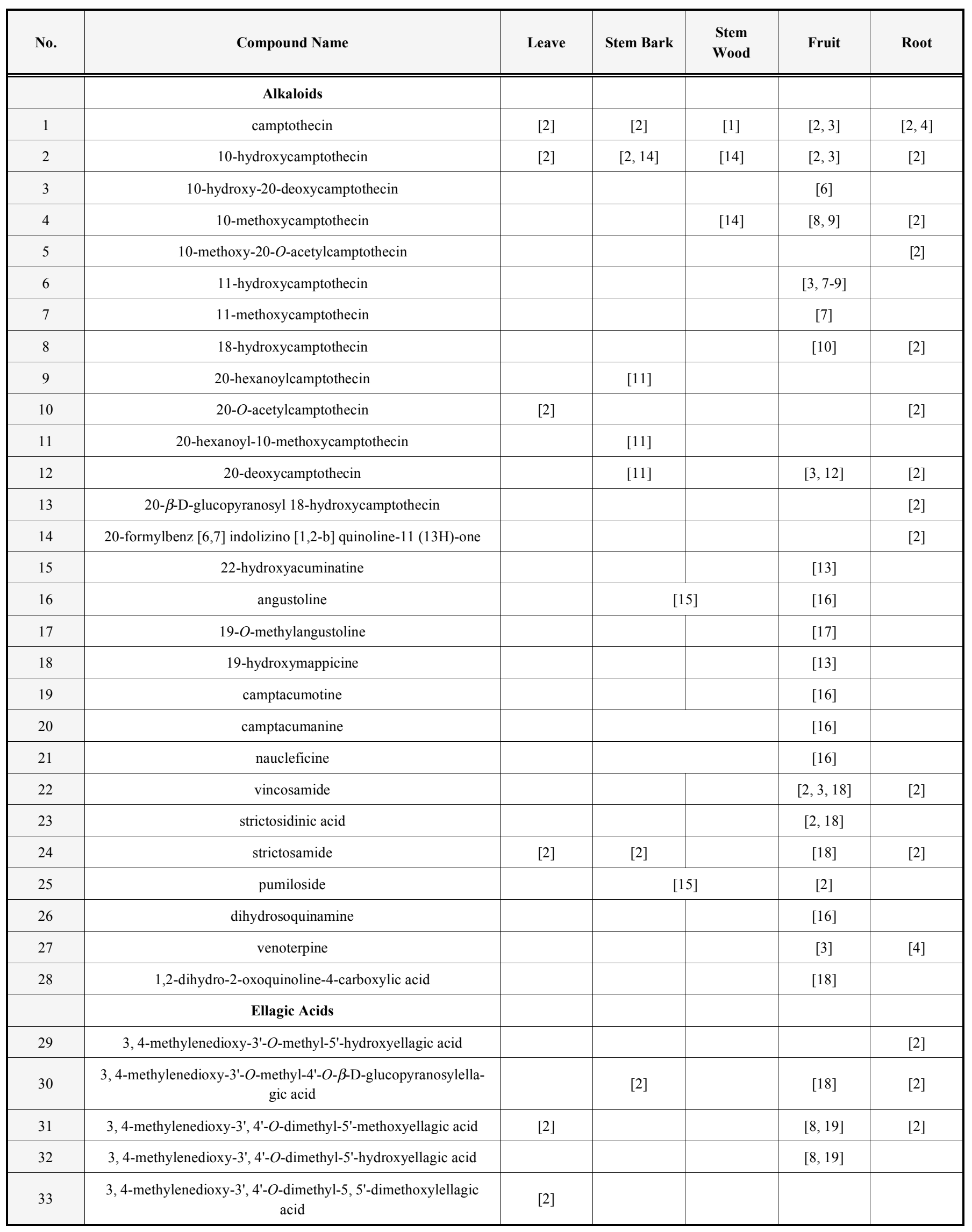


(Table 1) contd....

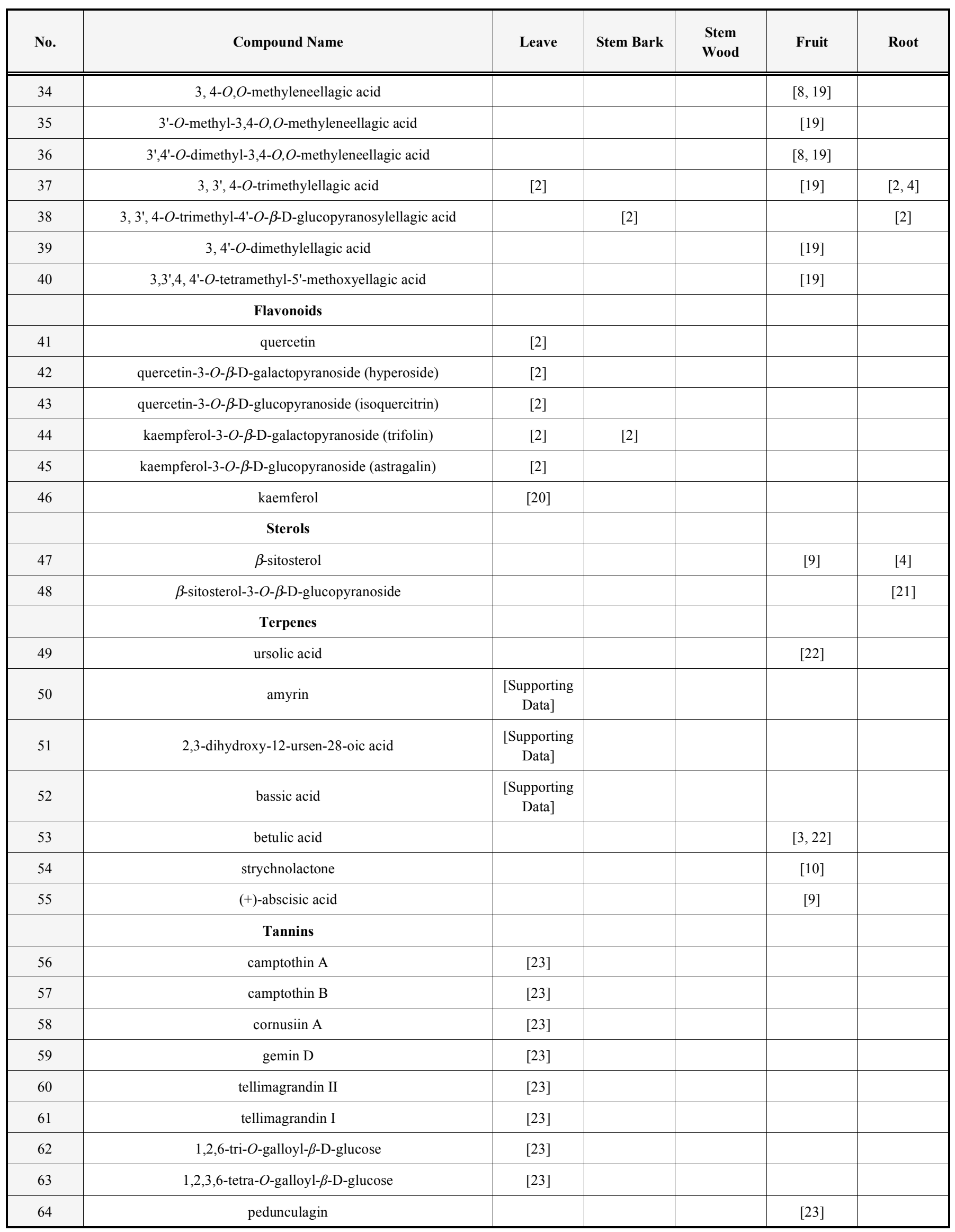


(Table 1) contd....

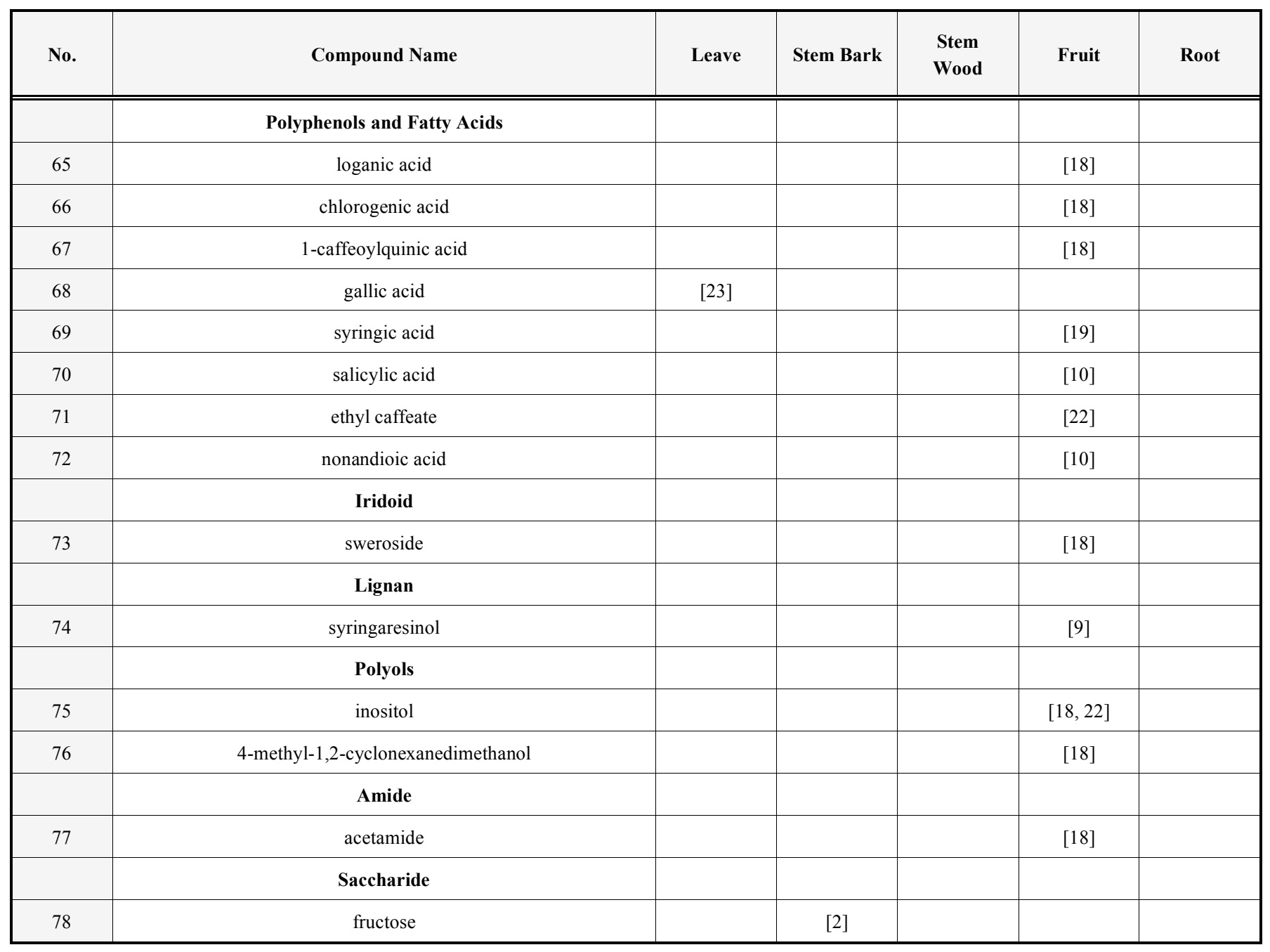

from the leave of $C$. acuminata (50-52). Amyrin (50), 2,3dihydroxy-12-ursen-28-oic acid (51), and bassic acid (52) were identified by Dr. Li' research team [Supporting Data]. One monoterpene (strychnolactone, 54) [10], and one sesquiterpene (abscisic acid 55) [9] were also reported from the fruit of C. acuminata.

\section{Tannins}

From the leaf of C. acuminata, camptothin A (56) and camptothin B (57) were isolated along with cornusiin A (58), gemin D (59), tellimagrandin II (60), tellimagrandin I (61), $1,2,6$-tri- $O$-galloyl- $\beta$-D-glucose (62), and 1,2,3,6-tetra- $O$ galloyl- $\beta$-D-glucose (63) [23]. Pedunculagin (64) was isolated from the fruit of C. acuminata [23].

\section{Polyphenols and Fatty Acids}

Seven aromatic compounds (65-71) and one long chain fatty acid (72) were isolated from $C$. acuminata. Loganic acid (65) [18], chlorogenic acid (66) [18], 1-caffeoylquinic acid (67) [18], syringic acid (69) [19], salicylic acid (70) [10] , ethyl caffeate (71) [22], and nonandioic acid (72) [10] were isolated or identified from fruits. Gallic acid (68) was isolated from the leaves [23].

\section{Miscellaneous Compounds}

Five other classes of compounds (73-78) were found from $C$. acuminata. Two polyols (75 and 76) [18, 22], one iridoid (73) [18], one lignan (74) [9], one amide (77) [18] were isolated from the fruit of $C$. acuminata. Compound $\mathbf{7 8}$ was identified from the stem bark of C. acuminata [2].

\section{VARIATIONS OF CPT CONTENTS}

Presently, the bioactive nature of secondary metabolites in plants, such as alkaloids, phenolics and terpenoids has made them medicinally important. CPT is the most wellknown example, which has shown a broad range of anticancer activity in animal models and continued to serve as a very attractive and challenging lead structure for the development of new anticancer drugs. To data, the extraction from C. acuminata is still considered as the main approach to obtain CPT compared with total synthesis. It becomes very important to understand content variations of CPT within and among plants, and with time. This review has also focused on presenting CPT variation among Camptotheca species and varieties, tissue and tree age, seasonal changes, and providing useful information for maximum yield of CPT and the discovery of novel camptothecinoids. 


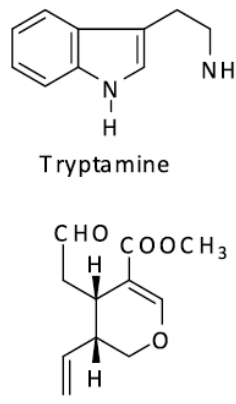

S ecologanin

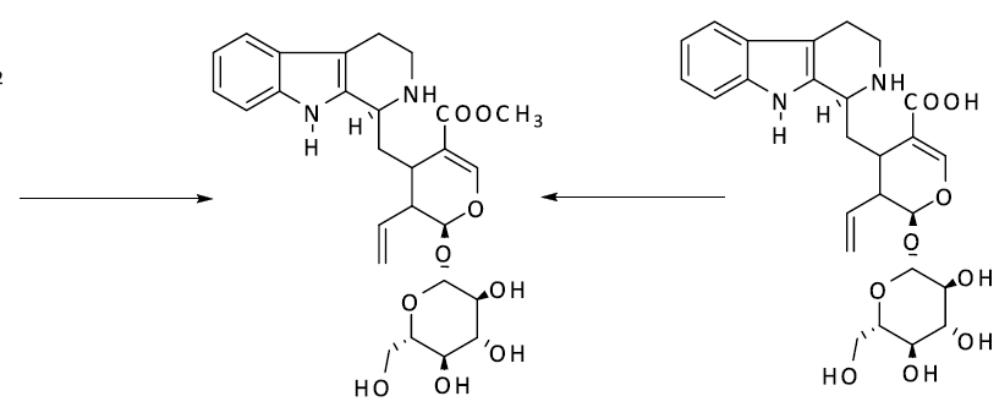

S trictosidine<smiles>C=CC1C(O)OC=C2C(=O)N3CCc4c([nH]c5ccccc45)C3CC21</smiles>

strictosidinic acid (23)

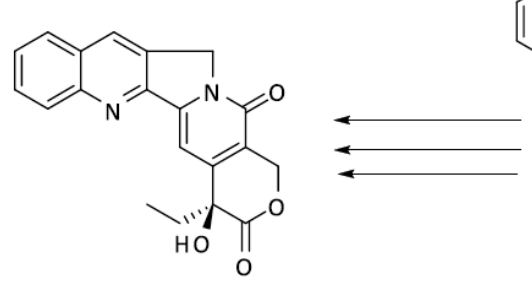

camptothecin (1)

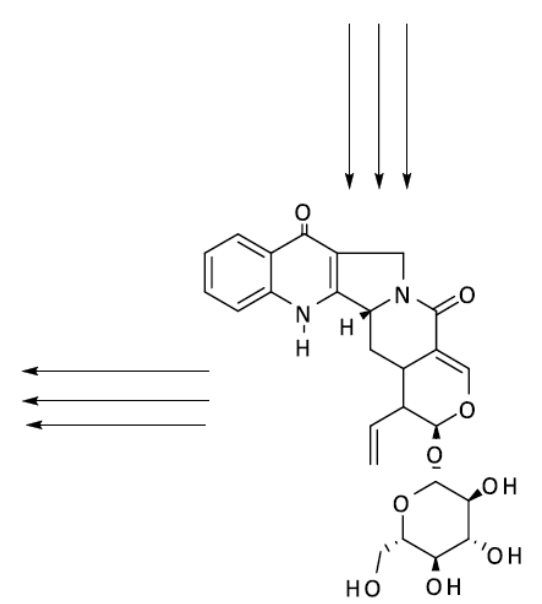

pumiloside (25)

Fig. (2). Hypothetical biogenetic pathway of camptothecin (CPT) (1).

\section{CPT Variations Among Species and Varieties}

Among all Camptotheca taxa, C. acuminata var. acuminata has the lowest CPT contents, from a maximum of $0.3162 \%$ to minimum of $0.2249 \%$ in young leaves, and from a maximum of $0.0572 \%$ to minimum of $0.0392 \%$ in older leaves. C. lowreyana "Hicksii" has the highest CPT contents in both young and old leaves, approximately 1.5-2 folds higher than those in $C$. acuminata var. acuminata (Table 2). C. lowreyana var. lowreyana, C. yunnanensis, and C. acuminata var. tenuifolia have not showed significant variation in young leaf CPT contents. C. lowreyana "Hicksii" and "Katie" was considered as the major management germplasm for CPT source by showing desirable features in both biomass and CPT concentration [24].

\section{CPT Variations within Plants}

These was evidenced early in 1977 that the CPT contents vary significantly within different tissues, although all parts of the C. acuminata plant contain some CPT (Table 3) [3, 4]. In our previous studies, the highest concentrations of CPT were found in the young leaves and mature fruit [24]. Young leaves $(<1$ weeks old) contained a mean CPT concentration of $0.2313 \%$, which was 26 -fold higher than that in young root $(<4$ weeks old), followed by young fruits $(<1$ weeks old) and young stems ( $<4$ weeks old) with a mean CPT concentration of $0.0842 \%$ and $0.0718 \%$ of dry weight, respectively. For old tissues, CPT content in fruit was 12-fold, 6fold, and 4-fold higher than in stems, roots, and leaves, respectively. Valletta et al. reported that the CPT concentration 
Table 2. CPT contents in young leaves (<1 week old) and old leaves (8-10 weeks) of Camptotheca Decaisne (\%, w/w, dry wt.) [24].

\begin{tabular}{|c|c|c|}
\hline Species/Variety & $\begin{array}{c}\text { CPT Content in Young Leaves } \\
\text { Average (Rang) }\end{array}$ & $\begin{array}{c}\text { CPT Content in Old Leaves } \\
\text { Average (Rang) }\end{array}$ \\
\hline \hline C. acuminata Decaisne & & $0.0482(0.0392-0.0572)$ \\
\hline var. acuminata & $0.2560(0.2249-0.3162)$ & N/A \\
\hline var. tenuifolia Fang et Soong & $0.3492(0.3247-0.3737)$ & $0.1184(0.1058-0.1310)$ \\
\hline C. lowreyana Li & & $0.0977(0.0900-0.1054)$ \\
\hline 'Hicksii' & $0.5537(0.5337-0.5737)$ & $0.0909(0.0765-0.1053)$ \\
\hline 'Katie' & $0.4778(0.4482-0.5074)$ & $0.0590(0.0491-0.0689)$ \\
\hline 'CT168' & 0.5890 & $0.3913(0.373-0.4096)$ \\
\hline
\end{tabular}

Table 3. CPT and 10-HCPT contents in different tissues of C. acuminata var. acuminata (\%, w/w, dry wt.).

\begin{tabular}{|c|c|c|c|c|c|c|c|}
\hline \multirow{2}{*}{ Tissue Type } & \multicolumn{2}{|c|}{ Young Tissue } & \multicolumn{2}{|c|}{ Intermediate Tissue } & \multicolumn{2}{|c|}{ Old Tissue } & \multirow{2}{*}{ Reference } \\
\hline & CPT & 10-CPT & CPT & 10-CPT & CPT & 10-CPT & \\
\hline Leaf & $0.2145-0.432$ & N/A & $0.1068-0.1138$ & N/A & $0.04-0.07$ & N/A & {$[24,25,28,29]$} \\
\hline Stem & $0.0648-0.0788$ & N/A & $0.0349-0.0377$ & $\mathrm{~N} / \mathrm{A}$ & $0.0181-0.048$ & $0.02-0.03$ & {$[24,26]$} \\
\hline Stem Wood & $0.0134-0.0138$ & N/A & $0.0079-0.0081$ & N/A & $0.0116-0.0122$ & N/A & {$[24]$} \\
\hline Stem Pith & $0.106-0.1104$ & N/A & UD & N/A & UD & $\mathrm{N} / \mathrm{A}$ & [24] \\
\hline Fruit & $0.0768-0.0916$ & N/A & $0.106-0.1104$ & N/A & $0.2234-0.28$ & $0.025-0.032$ & {$[24-26,29]$} \\
\hline
\end{tabular}

Notes: N/A-no data available; UD-Undetectable.

in the mature fruit was $0.28 \%$, which is similar to the $0.2312 \%$ in our study [25]. The authors described also CPT variations in the young leaves $(0.011 \%-0.0432 \%)$ and very young roots $(0.015-0.025 \%)$. Pi et al. investigated the contents of CPT and 10-HCPT in different tissues including roots, stems, leaves, young flower buds, opening flowers, fading flowers and seeds from C. acuminata [26]. The young flower buds had also found having the highest alkaloid concentrations with a mean CPT concentration of $0.246 \%$ and 10 -HCPT of $0.141 \%$ of dry weight.

Of particular interest was the finding that CPT content is obviously related to tissue age rather than its location on the plant and tree age [24]. Against this background, although no detailed descriptions about leaf materials were given, it is likely that young tissue was used in the CPT analysis in some previous studies [1, 20, 27-30], while some negative results may had been caused by the use of relatively old tissue in the analyses [26, 28, 31, 32]. So, in conclusion, only fruits and young leaves of Camptotheca are currently suitable for CPT extract.

\section{CPT Variations with Seasons}

There was significant seasonal variation in CPT concentration in C. acuminata var. acuminata over the course of the growing season. Liu et al. found a steady decline of $11 \%$ per month in leaf CPT concentration from a maximum of $0.051 \%$ in April to a minimum of $0.017 \%$ in October. Branches showed a similar seasonal decline in CPT concentration to leaves from a maximum of $0.018 \%$ in April to a minimum of $0.011 \%$ in October. However, the rate of decline was threefold greater in leaves than in branches [28]. Our research results are very different from these statements [24]. In intact young tissues, significant seasonal change were showed with the lowest CPT contents in March and April (0.074\% and $0.081 \%$, respectively) and highest in June $(0.265 \%)$ in C. acuminata var. acuminata, and no significant difference among May and July to October (0.117-0.171\%). It was reported that CPT contents in mature fruits (usually in September to October) are 2-3 times of those in young fruits or flowers (in May to June). In additional, the seasonal changes of CPT in intact young tissues and fruits have con- 
firmed indirectly the studies on CPT variations with tissue age.

\section{CONFLICT OF INTEREST}

The authors confirm that this article content has no conflict of interest.

\section{ACKNOWLEDGEMENTS}

Declared none.

\section{PATIENT'S CONSENT}

Declared none.

\section{REFERENCES}

[1] Wall, M.E.; Wani, M.C.; Cook, C.E.; Palmer, K.H.; McPhail, A.T.; Sim, G.A. Plant antitumor agents. I. Isolation and structure of camptothecin, a novel alkaloidal leukemia and tumor inhibitor from Camptotheca acuminata. J. Am. Chem. Soc., 1966, 88(16), 38883890.

[2] Zhang, Z.Z.; Li, S.Y.; Zhang, S.M.; Liang, C.; Gorenstein, D.; Beasley, R.S. New camptothecin and ellagic acid analogues from the root bark of Camptotheca acuminata. Planta Med., 2004, 70, 1216-1221.

[3] Hsu, J.S.; Chao, T.Y.; Lin, L.T.; Hsu, C.F. Chemical constituents of the anticancer plant Camptotheca acuminata Decne. II. Chemical constituents of the fruits of Camptotheca acuminata Decne. Huaxue Xuebao, 1977, 35(4), 193-200.

[4] Lin, L.T.; Chao, T.Y.; Hsu, J.S. Chemical constituents of the anticancer plant Camptotheca acuminata Decne. I. Chemical constituents of the roots of Camptotheca acuminata Decne. Huaxue Xuebao, 1977, 35(3-4), 227-231.

[5] Lu, A.J.; Zhang, Z.S.; Zheng, M.Y.; Zou, H.J.; Luo, X.M.; Jiang, H.L. 3D-QSAR study of 20 (S)-camptothecin analogs. Acta Pharmacol. Sin., 2007, 28(2), 307-314.

[6] Lin, L.Z.; Shen, J.H.; Zhou, T.; Shen, C.Y.; Ke, M.M. New alkaloid 10-hydroxydeoxycamptothecin. Huaxue Xuebao, 1989, 47(5), 506-508.

[7] Lin, L.Z; Sung, C.C.; Hsu, R.S. A new anticancer alkaloid 11hydroxycamptothecin. Kexue Tongbao, 1979, 24(10), 478-479.

[8] Lin, L.T.; Sung, C.C.; Hsu, J.S. Chemical constituents of the anticancer plant Camptotheca acuminata Decne. V. Other constituents of its fruits. Huaxue Tongbao, 1978, 6, 327-328.

[9] Lin, L.Z.; Song, C.Q.; Xu, R.S. Chemical constituents of the anticancer plant Camptotheca acuminata Decne. IV. Isolation and identification of 11-hydroxycamptothecin and other four compounds. Huaxue Xuebao, 1982, 40(1), 85-89.

[10] Lin, L.Z.; Zhang, J.S.; Shen, J.H.; Zhou, T.; Zhang, W.Y. A new alkaloid - 18-hydroxycamptothecin. Yaохие Хиеbao, 1988, 23(3), 186-188.

[11] Adamovics, J.A.; Cina, J.A.; Hutchinson, C.R. Minor alkaloids of Camptotheca acuminata. Phytochemistry, 1979, 18(6), 1085-1086.

[12] Nanjing College Isolation of deoxycamptothecin, a minor alkaloid from fruits of Camptotheca acuminata. Pharmacol. Data 1974, 4(9), 4-8.

[13] Lin, L.Z.; Cordell, G.A. Quinoline alkaloids from Camptotheca acuminata. Phytochemistry, 1989, 28(4), 1295-1297.

[14] Wani, M.C.; Wall, M.E. Plant antitumor agents. II. Structure of two new alkaloids from Camptotheca acuminata. J. Org. Chem., 1969, 34(5), 1364-1367.
[15] Carte, B.K.; Debrosse, C.; Eggleston, D.; Hemling, M.; Mentzer, M.; Poehland, B.; Troupe, N.; Westley, J.W. Isolation and characterization of a presumed biosynthetic precursor of camptothecin from extracts of Camptotheca acuminata. Tetrahedron, 1990, 46(8), 2747-2760.

[16] Lin, L.Z.; Shen, J.H.; He, X.; Zhang, W.Y. Indole alkaloids from Camptotheca acuminata. Huaxue Xuebao, 1988, 46(12), 12071211.

[17] Lin, L.Z.; Cordell, G.A. 9-O-methylangustoline from Camptotheca acuminata. Phytochemistry, 1990, 29, 2744-2746.

[18] Yin, F.; Hu, L.H. Two DNA topoisomerase I inhibitors from Camptotheca acuminata Decne. (Nyssaceae). Zhongguo Tianran Yaowu, 2005, 3(1), 21-24.

[19] Lin, L.Z.; Song, C.Q.; Xu, R.S. Chemical constituents of the anticancer plant Camptotheca acuminata Decne. III. Ellagic acids from the fruits of Camptotheca acuminata Decne. Huaxue Xuebao, 1979, 37(3), 207-214.

[20] Tien, H.J.; Tien, J.M.; Yeh, M.Y.; Wu, T.S.; Huang, C.M. Studies on the constituents of Camptotheca acuminata Decne (I) the constituents of leaves. Chemistry, 1977, 2, 51-54.

[21] Wu, T.S.; Tien, H.J.; Yeh, M.Y. Studies on the constituents of Formosan folk medicine. VII. Constituents of the flowers of Vanilla somai Hayata and the roots of Camptotheca acuminata Decne. Chenggong Daxue Xuebao, 1980, 15, 65-67.

[22] Wu, T.S.; Chen, M.T.; Kuoh, C.S.; Tien, H.J.; Yeh, M.Y. Studies on the constituents of Camptotheca acuminata Decne, II. The constituents of fresh fruits. J. Chin. Chem. Soc., 1985, 32(2), 173175 .

[23] Hatano, T.; Ikegami, Y.; Shingu, T.; Okuda, T. Camptothins A and $\mathrm{B}$, new dimeric hydrolyzable tannins from Camptotheca acuminata Decne. Chem. Pharm. Bull., 1988, 36(6), 2017-2022.

[24] Li, S.Y.; Yi, Y.J.; Wang, Y.J.; Zhang, Z.Z.; Beasley, R.S Camptothecin accumulation and variations in Camptotheca. Planta Med., 2002, 68, 1010-1016.

[25] Valletta, A.; Santamaria, A.R.; Pasqua, G. CPT accumulation in the fruit and during early phases of plant development in Camptotheca acuminata Decaisne (Nyssaceae). Nat. Prod. Res., 2007, 21(14), 1248-1255.

[26] Pi, Y.; Jiang, K.; Hou, R.; Gong, Y.; Lin, J.; Sun, X.; Tang, K. Examination of camptothecin and 10-hydroxycamptothecin in Camptotheca acuminata plant and cell culture, and the affected yields under several cell culture treatments. Biocell, 2010, 34(3), 139-143.

[27] Liu, Z.; Adams, J. Seed source variation in camptothecin concentrations of nursery-grown Camptotheca acuminata seedlings. New Forests, 1998, 16, 167-175.

[28] Liu, Z.; Carpenter, S.B.; Bourgeois, W.J.; Yu, Y.; Constantin, R.J.; Falcon, M.J.; Adams, J. Variations in the secondary metabolite camptothecin in relation to tissue age and season in Camptotheca acuminata. Tree Physiol., 1998, 18, 265-270.

[29] López-Meyer, M.; Nessler, C.L.; McKnight, T.D. Sites of Accumulation of the Antitumor Alkaloid Camptothecin in Camptotheca acuminata. Planta Med., 1994, 60(6), 558-560.

[30] Li, S.Y. Camptotheca lowreyana, a new species of anti-cancer happytrees (Camptotheca Decaisne). Bull. Bot. Res., 1997, 17, 348352.

[31] Perdue, R.E.; Smith, R.L.; Wall, M.E.; Hartwell, J.L.; Abbott, B.J. Camptotheca acuminate Decaisne (Nyssaceae) source of camptothecin, and antileukemic alkaloid. Agriculturral Research Series USDA Technical Bulletin: 1977.

[32] Liu, Z.; Adams, J. Camptothecin yield and distribution within Camptotheca acuminata trees cultivated in Louisiana. Can. J. Bot., 1996, 74, 360-365. 